\title{
Edukasi tentang Suplemen Kesehatan dalam Menghadapi Covid-19 di Desa Sumbersuko Kabupaten Malang
}

DOI: https://doi.org/10.32509/abdimoestopo.v5i1.1808

\author{
Rizta Widya Pangestika ${ }^{*}$, Rudy Mardianto², Dzikrina Ilmanita ${ }^{3}$, Nanang Ardianto ${ }^{4}$ \\ Progam Studi Farmasi Klinis dan Komunitas Institut Teknologi Sains, dan \\ Kesehatan RS dr. Soepraoen \\ Jalan Soedanco Supriadi No 22, Kota Malang, Jawa Timur, Indonesia 65147 \\ *Email Korespondensi: riztawidya@itsk-soepraoen.ac.id
}

\begin{abstract}
$\overline{\text { Abstract - Covid-19 in Indonesia is widespread in almost all provinces, including East Java. The amount }}$ of information related to health supplement products circulating in the community can cause anxiety and even interfere with the supply of ingredients, including some health supplement products needed during pandemics. This community service activity was carried out in Sumbersuko Village of Wagir Subdistrict. The purpose of this community service is to increase partners knowledge about health supplements, partners can find out information about vitamin $C$, and get to know efforts to deal with COVID-19. The target of this community service activity is Village Cadres Sumbersuko. The method of implementing the activity is by providing education about health supplements in dealing with COVID19. Education participants were also given pocket books for health supplements and vitamin $C$. Participants were very enthusiastic in the educational process as evidenced by the emergence of many questions from participants. With this community service activity, Village Cadres can understand the use of health supplements in an effort to deal with COVID-19. The next follow-up is that the Village Cadres will return the results of the information and knowledge that has been obtained to the village community.
\end{abstract}

Keywords: Education, health supplements, vitamin C, COVID-19

Abstrak - Covid-19 di Indonesia tersebar luas hampir di semua provinsi, termasuk Jawa Timur. Banyaknya informasi terkait produk suplemen kesehatan yang beredar di masyarakat dapat menimbulkan keresahan bahkan mengganggu pasokan bahan-bahan, termasuk beberapa produk suplemen kesehatan yang dibutuhkan selama pandemi. Kegiatan pengabdian masyarakat ini dilaksanakan di Desa Sumbersuko Kecamatan Wagir. Tujuan pengabdian masyarakat ini yaitu untuk meningkatkan pengetahuan mitra tentang suplemen kesehatan, mitra dapat mengetahui informasi tentang vitamin $\mathrm{C}$, dan mengenal upaya untuk menghadapi COVID-19. Sasaran dari kegiatan pengabdian masyarakat ini adalah Kader Desa Sumbersuko. Metode pelaksanaan kegiatan yaitu dengan memberikan edukasi tentang suplemen kesehatan dalam menghadapi COVID-19. Peserta edukasi juga diberikan buku saku suplemen kesehatan dan vitamin C. Peserta sangat antusias dalam proses edukasi yang terbukti dengan munculnya banyak pertanyaan dari peserta. Dengan adanya kegiatan pengabdian masyarakat ini, Kader Desa dapat memahami tentang penggunaan suplemen kesehatan dalam upaya menghadapi COVID-19. Tindak lanjut kedepannya yaitu para Kader Desa akan menyampaikan kembali hasil informasi dan pengetahuan yang telah didapatkan kepada masyarakat desa.

Kata Kunci: Edukasi, suplemen kesehatan, vitamin C, COVID-19 


\section{PENDAHULUAN}

Coronavirus disease (COVID-19) adalah penyakit menular yang disebabkan oleh virus Severe Acute Respiratory Syndrome Coronavirus-2 (SARS-CoV-2). Coronavirus muncul pertama kali di kota Wuhan, Provinsi Hubei, Cina pada Desember 2019 (Wu et al., 2020). World Health Organization (WHO) telah menyatakan bahwa COVID-19 sebagai global pandemic (Menteri Kesehatan Republik Indonesia, 2020). Pada COVID-19, Coronavirus menginfeksi paru dan berkembangbiak. Selanjutnya, pertahanan tubuh akan memberikan respon, apabila pertahanan tubuh lemah maka dapat terjadi peradangan serta cedera paru sehingga akan muncul gejala penyakit (Fehr \& Perlman, 2015).

Studi epidemiologi dan virologi membuktikan bahwa COVID-19 utamanya ditularkan dari orang yang bergejala (simptomatik) ke orang lain yang berada jarak dekat melalui droplet. Infeksi ditularkan melalui droplet yang dihasilkan selama batuk dan bersin oleh pasien bergejala tetapi juga dapat terjadi dari orang tanpa gejala dan sebelum timbulnya gejala (Singhal, 2020). Droplet merupakan partikel berisi air dengan diameter $>5-10 \mu \mathrm{m}$. Penularan droplet terjadi ketika seseorang berada pada jarak dekat (dalam 1 meter) dengan seseorang yang memiliki gejala pernapasan (misalnya, batuk atau bersin) sehingga droplet berisiko mengenai mukosa atau konjungtiva. Penularan juga dapat terjadi melalui benda dan permukaan yang terkontaminasi droplet di sekitar orang yang terinfeksi. Oleh karena itu, penularan virus COVID-19 dapat terjadi melalui kontak langsung dengan orang yang terinfeksi dan kontak tidak langsung dengan permukaan atau benda yang digunakan pada orang yang terinfeksi (Kementerian Kesehatan Republik Indonesia, 2020).

Gejala-gejala yang dialami biasanya bersifat ringan dan muncul secara bertahap. Beberapa orang yang terinfeksi tidak menunjukkan gejala apapun dan tetap merasa sehat. Gejala COVID-19 yang paling umum adalah demam, rasa lelah, dan batuk kering. Beberapa pasien mungkin mengalami rasa nyeri dan sakit, hidung tersumbat, pilek, nyeri kepala, konjungtivitis, sakit tenggorokan, diare, hilang penciuman dan pembauan atau ruam kulit. Pada kasus COVID-19 yang berat dapat menyebabkan pneumonia, sindrom pernapasan akut, gagal ginjal, dan bahkan kematian (Baj et al., 2020; Kementerian Kesehatan Republik Indonesia, 2020).

Di Indonesia, COVID-19 dinyatakan sebagai jenis penyakit yang menimbulkan kedaruratan kesehatan masyarakat serta bencana nonalam, yang tidak hanya menyebabkan kematian tetapi juga menimbulkan kerugian ekonomi yang cukup besar, sehingga perlu dilakukan upaya penanggulangan termasuk pencegahan dan pengendaliannya (Menteri Kesehatan Republik Indonesia, 2020). Salah satu upaya pencegahan yang dapat dilakukan adalah dengan meningkatkan ketahanan masyarakat, melalui kesehatan tubuh perorangan. Daya tahan tubuh dapat dijaga dan ditingkatkan, utamanya melalui kebiasaan hidup sehat antara lain menjaga kebersihan, asupan nutrisi yang baik, ditambah dengan penggunaan suplemen kesehatan dan ramuan herbal/obat tradisional (Badan POM RI, 2020b).

Suplemen kesehatan mengandung bahan-bahan mikronutrien berupa trace mineral dan vitamin yang diperlukan sebagai nutrisi esensial bagi tubuh. Kurang memadainya asupan mikronutrien dapat mengganggu respon imun nonspesifik dan spesifik saat tubuh menghadapi virus atau bakteri. Hal tersebut dapat menimbulkan kerentanan terhadap infeksi yang akan meningkatkan angka kesakitan (morbiditas) dan angka kematian (mortalitas) (Badan POM RI, 2020b). Penggunaan suplemen kesehatan dalam upaya pencegahan COVID-19 berfungsi untuk melengkapi kekurangan vitamin pada kondisi tertentu sehingga sistem imun dapat berfungsi secara optimal (Mishra \& Patel, 2020). Diperlukan informasi mengenai suplemen kesehatan agar masyarakat dapat memilih dan menggunakan suplemen kesehatan secara tepat dan bijak untuk menghadapi COVID-19. 
Beberapa bahan suplemen kesehatan yang memiliki peran dalam fungsi normal daya tahan tubuh manusia yaitu Vitamin C, Vitamin D, Vitamin E, probiotik, Zink, Selenium. Vitamin $\mathrm{C}$ merupakan nutrisi penting yang terlibat dalam berbagai proses enzimatik dalam sistem kekebalan tubuh dan juga memiliki fungsi fisiologis lain dalam tubuh manusia (Kashiouris M.G., L'Heureux M., Cable C.A., Fisher B.J., 2020). Sebelumnya, Vitamin C telah diusulkan memiliki manfaat teoretis dalam pertahanan kekebalan terhadap infeksi COVID-19, berdasarkan sifat yang diketahui dan hipotesis, serta ada bukti yang mendukung perannya dalam mitigasi gejala pada flu biasa (Farjana et al., 2020; Hemila, 2017; Hemilä \& Chalker, 2013).

Wagir merupakan salah satu daerah dari 33 kecamatan di wilayah Kabupaten Malang, Jawa Timur. Berdasarkan data Badan Pusat Statistik Kabupaten Malang tahun 2019, Desa Sumbersuko yang berada di Kecamatan Wagir memiliki sarana kesehatan yaitu 1 Puskesmas Pembantu dan memiliki 1 Bidan. Pada bulan Februari 2021, data sebaran COVID-19 di Kecamatan Wagir yaitu suspek sejumlah 103 orang dan terkonfirmasi positif Covid-19 sejumlah 69 orang.

Berdasarkan observasi awal, belum semua masyarakat Desa Sumbersuko memahami bagaimana penggunaan suplemen kesehatan yang tepat dalam upaya menghadapi COVID-19. Hal inilah yang menjadi latar belakang untuk melaksanakan kegiatan pengabdian masyarakat berupa edukasi tentang suplemen kesehatan dalam upaya menghadapi COVID-19 di Desa Sumbersuko Kecamatan Wagir Kabupaten Malang. Tujuan kegiatan pengabdian masyarakat ini yaitu untuk meningkatkan pengetahuan mitra tentang suplemen kesehatan, mitra dapat mengetahui informasi tentang vitamin C, dan mengenal upaya dalam menghadapi COVID-19. Edukasi diberikan kepada Kader Desa Sumbersuko karena kader berperan sebagai penggerak utama dan terdepan dalam perubahan pengetahuan, sikap, dan perilaku masyarakat Desa. Tindak lanjut kedepannya yaitu para Kader Desa akan menyampaian kembali hasil informasi dan pengetahuan yang telah didapatkan kepada masyarakat desa. Diharapakan setelah kegiatan pengabdian masyarakat ini dilakukan, masyarakat Desa Sumbersuko memiliki informasi dan pemahaman yang benar terkait penggunaan suplemen kesehatan dalam menghadapi Covid-19.

\section{METODE PELAKSANAAN}

Kegiatan pengabdian masyarakat oleh Prodi S1 Farmasi Klinis dan Komunitas Institut Teknologi, Sains, dan Kesehatan (ITSK) RS dr. Soepraoen dilaksanakan pada tanggal 4 September 2021. Tim pengabdian masyarakat terdiri dari Dosen dan mahasiswa. Kegiatan pengabdian masyarakat dilaksanakan di Balai Desa Sumbersuko, Kecamatan Wagir, Kabupaten Malang. Sasaran dari kegiatan pengabdian masyarakat ini adalah Kader Desa Sumbersuko.

Kegiatan yang telah dilakukan dalam pengabdian ini terdiri dari 3 tahapan, yaitu:

1. Tahap persiapan

Tahapan ini dimulai dengan berkoordinasi dengan Kepala Desa Sumbersuko terkait persiapan kegiatan yang meliputi perizinan, waktu kegiatan, lokasi kegiatan, susunan acara hingga peserta pengabdian masyarakat. Selanjutnya tim pengabdian masyarakat melakukakan identifikasi kebutuhan kegiatan pengabdian masyarakat dan mempersiapakan materi edukasi.

2. Tahap pelaksanaan

Kegiatan ini dilaksanakan dengan tetap memperhatikan protokol kesehatan. Metode yang digunakan yaitu dengan memberikan edukasi tentang suplemen kesehatan dalam menghadapi Covid-19, pemberian buku saku, dan pembagian suplemen kesehatan yaitu vitamin C. Materi edukasi disampaikan oleh tim Dosen dari Program Studi S1 Farmasi Klinis dan Komunitas S1 Farmasi Klinis dan Komunitas Institut Teknologi, Sains, dan Kesehatan (ITSK) RS dr. Soepraoen. Materi edukasi yaitu tentang pengertian dari suplemen kesehatan, tujuan penggunaan suplemen kesehatan, sistem imun, informasi tentang vitamin $C$, sumber-sumber 
vitamin $\mathrm{C}$, bagaimana vitamin $\mathrm{C}$ bekerja untuk daya tahan tubuh, aturan di Indonesia terkait penggunaan vitamin $\mathrm{C}$, pengertian COVID-19, serta upaya-upaya meningkatkan daya tubuh salah satunya dengan mengkonsumsi suplemen kesehatan.

3. Tahap evaluasi

Tahapan evaluasi dilakukan dengan membuka sesi tanya jawab setelah materi edukasi diberikan kepada Kader Desa. Tindak lanjut kedepannya yaitu Kader Desa akan mensosialisasikan materi edukasi yang diberikan kepada masyarakat Desa.

\section{HASIL DAN PEMBAHASAN}

Suplemen Kesehatan adalah produk yang dimaksudkan untuk melengkapi kebutuhan zat gizi, memelihara, meningkatkan dan/atau memperbaiki fungsi kesehatan, mempunyai nilai gizi dan/atau efek fisiologis, mengandung satu atau lebih bahan berupa vitamin, mineral, asam amino dan/atau bahan lain bukan tumbuhan yang dapat dikombinasi dengan tumbuhan (Badan POM RI, 2019). Sejauh ini, klaim khasiat/manfaat yang telah disetujui olah Badan Pengawas Obat dan Makanan Republik Indonesia (BPOM RI) terkait suplemen kesehatan untuk menghadapi pandemi COVID-19 masih sebatas membantu memelihara daya tahan tubuh. Belum pernah disetujui produk herbal dan suplemen kesehatan dengan klaim mencegah atau mengobati penyakit yang disebabkan oleh virus (antivirus), termasuk penyakit COVID-19 yang disebabkan oleh infeksi novel coronavirus, tanpa adanya uji klinik baik di negara lain maupun di Indonesia (Badan POM RI, 2020b).

Vitamin C merupakan salah satu suplemen kesehatan. Vitamin $\mathrm{C}$ yang juga dikenal sebagai asam L-askorbat merupakan vitamin yang larut dalam air (PaLykkesfeldt, 2014). Vitamin $\mathrm{C}$ berkontribusi untuk daya tahan tubuh dengan mendukung berbagai fungsi seluler pada sistem kekebalan tubuh (innate immune dan adaptive immune) (Carr, A. C.; Maggini, 2017). Vitamin C (asam askorbat) memainkan peran penting dalam fungsi normal sistem kekebalan tubuh (Bozonet \& Carr, 2019). Vitamin C berkontribusi untuk daya tahan tubuh dengan mendukung berbagai fungsi seluler baik dari sistem imun bawaan maupun adaptif (Carr, A. C.; Maggini, 2017).

Kegiatan pengabdian masyarakat ini dilaksanakan pada tanggal 4 September 2021 di Balai Desa Sumbersuko Kecamatan Wagir Kabupaten Malang. Sasaran pada pengabdian masyarakat ini adalah Kader Desa Sumbersuko. Kegiatan pengabdian masyarakat dihadiri oleh sekitar 15 Kader Desa Sumbersuko. Tujuan pengabdian masyarakat ini yaitu untuk meningkatkan pengetahuan mitra tentang suplemen kesehatan, mitra dapat mengetahui informasi tentang vitamin $\mathrm{C}$, dan mengenal upaya dalam menghadapi COVID-19. Kegiatan pengabdian masyarakat ini tetap menerapkan protokol kesehatan yaitu Kader yang datang diwajibkan menggunakan masker dan menggunakan hand sanitizer terlebih dahulu. Peserta kegiatan pengabdian masyarakat yang hadir diberikan buku saku serta vitamin C sebagai sarana informasi dan edukasi. 


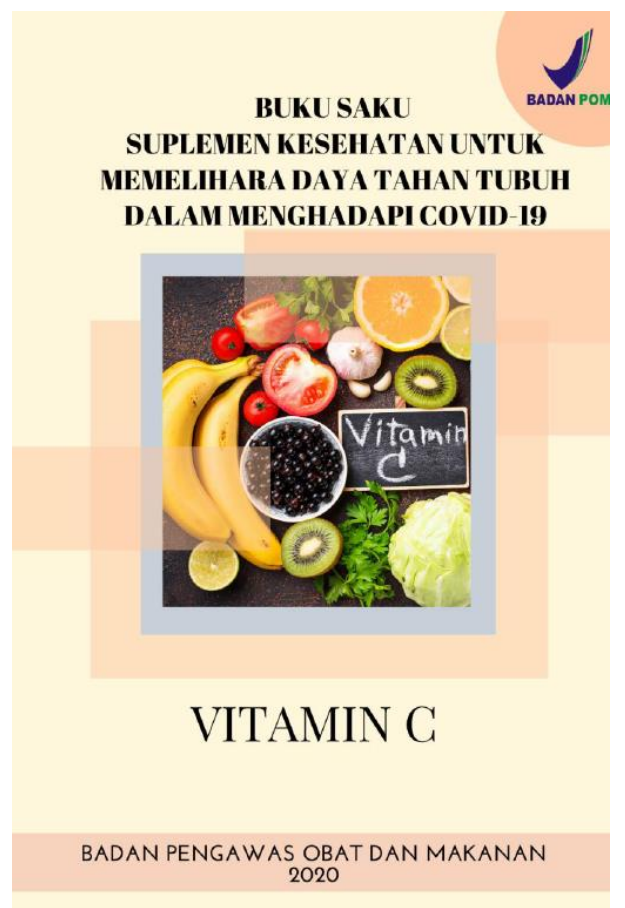

Gambar 1. Buku saku suplemen kesehatan

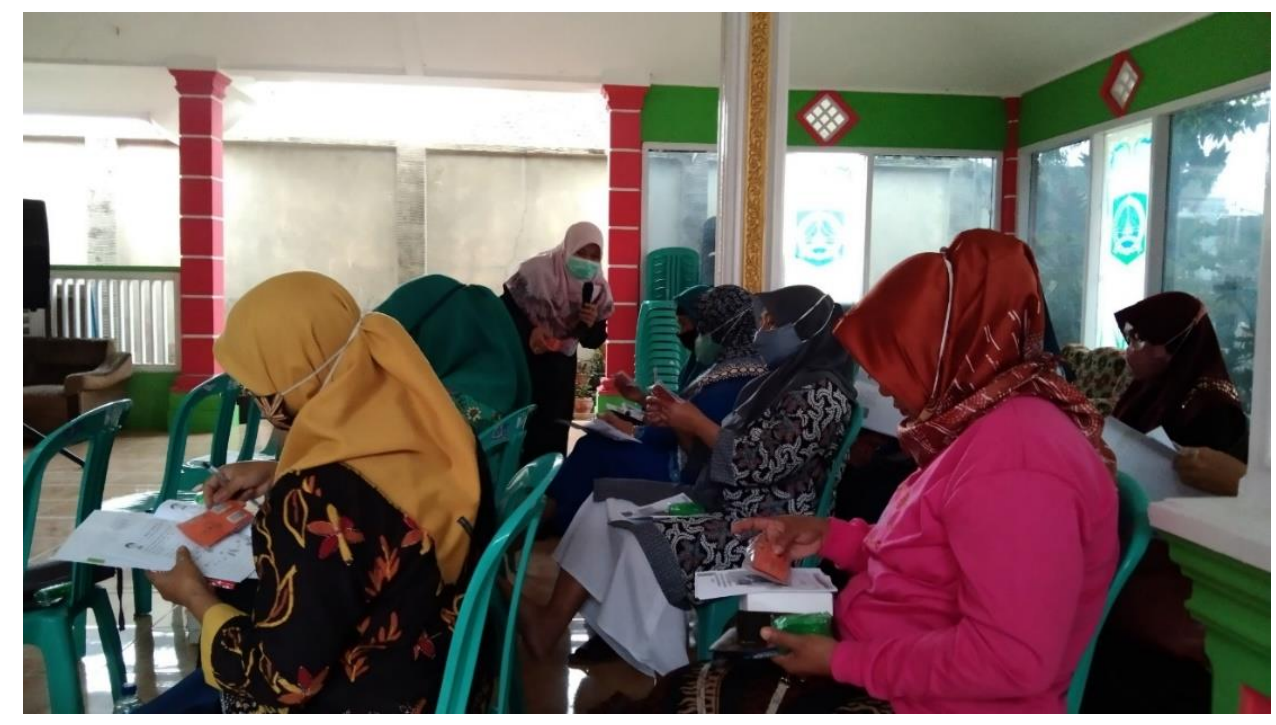

Gambar 2. Pemberian buku saku suplemen kesehatan dan vitamin C 


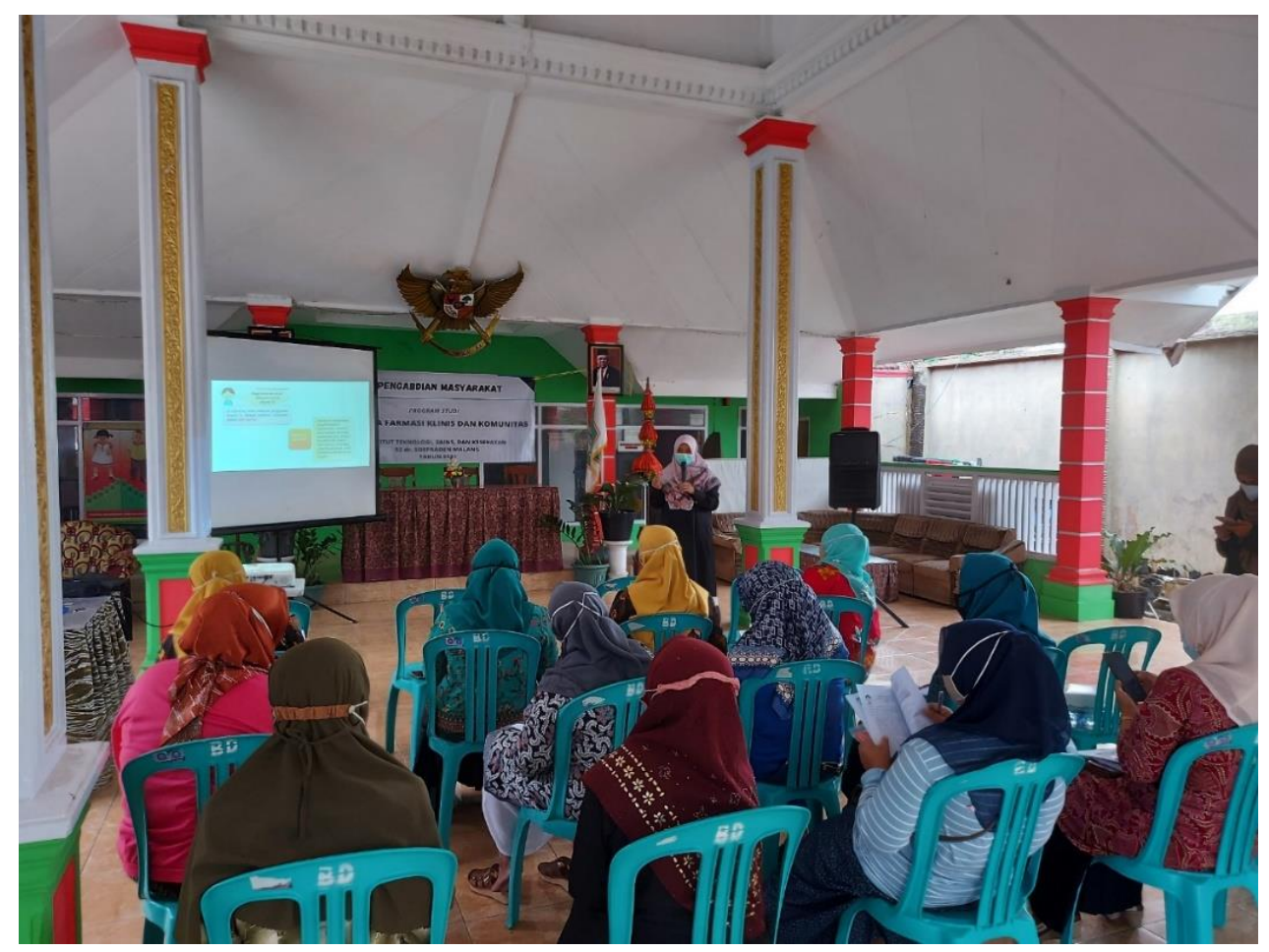

Gambar 3. Pelaksanaan edukasi tentang suplemen kesehatan

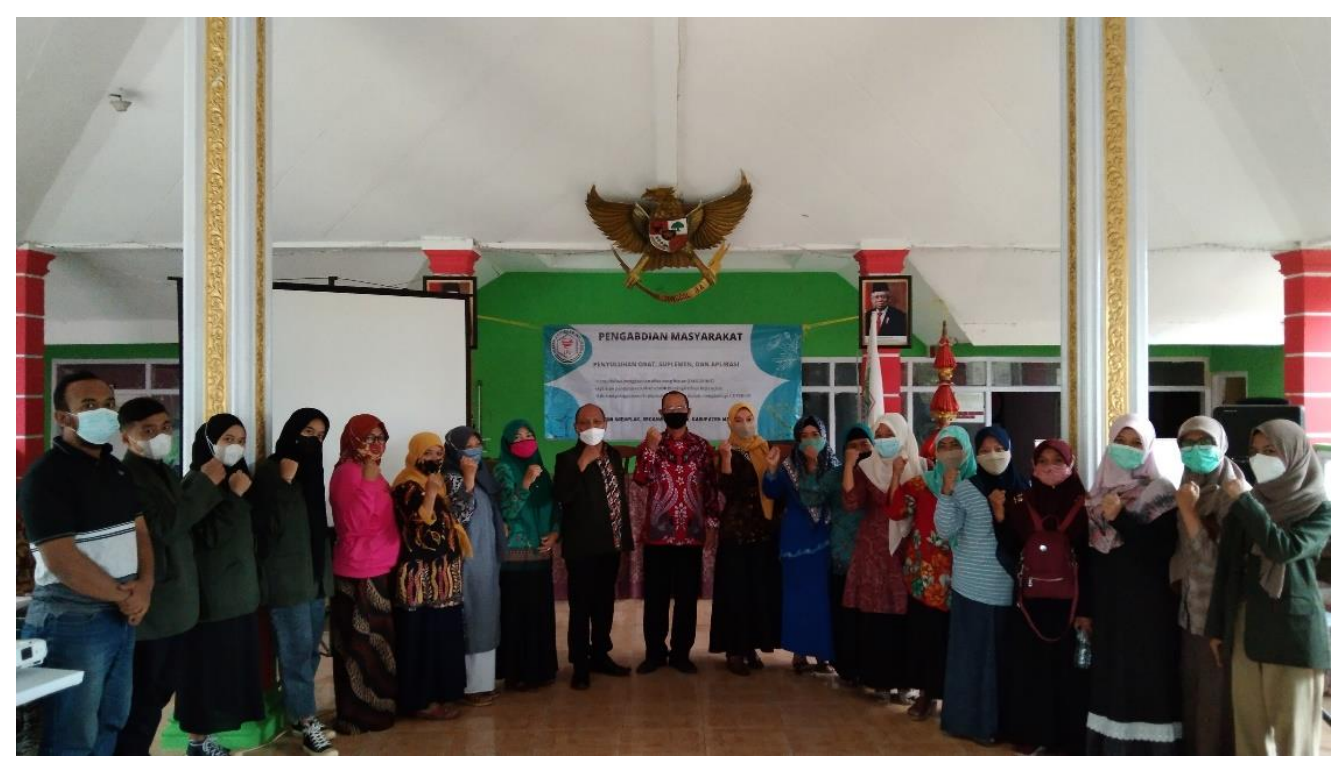

Gambar 4. Foto bersama dengan peserta pengabdian

Kegiatan pengabdian masyarakat dimulai dengan pemberian edukasi tentang suplemen kesehatan dalam menghadapi COVID-19. Materi edukasi yang disampaikan yaitu tentang pengertian dari suplemen kesehatan, tujuan penggunaan suplemen kesehatan, sistem imun, informasi tentang vitamin $C$, sumber-sumber vitamin $C$, bagaimana vitamin $C$ bekerja untuk daya tahan tubuh, aturan di Indonesia terkait penggunaan vitamin $\mathrm{C}$, pengertian COVID-19, serta upaya-upaya meningkatkan daya tubuh salah satunya dengan mengkonsumsi suplemen kesehatan. 
Beberapa materi yang ditekankan dalam edukasi yaitu (Badan POM RI, 2020a):

a. Pengertian Suplemen Kesehatan

Suplemen kesehatan merupakan produk yang dimaksudkan untuk melengkapi kebutuhan zat gizi, memelihara, meningkatkan dan/atau memperbaiki fungsi kesehatan, mempunyai nilai gizi dan/atau efek fisiologis, mengandung satu atau lebih bahan berupa vitamin, mineral, asam amino dan/atau bahan lain bukan tumbuhan yang dapat dikombinasi dengan tumbuhan.

b. Tujuan penggunaan suplemen kesehatan

Penggunaan suplemen kesehatan tidak untuk mengobati/ menggantikan obat yang digunakan dalam menyembuhkan suatu penyakit; penggunaan suplemen kesehatan tidak bertujuan untuk menggantikan makanan sehari-hari; penggunaan suplemen kesehatan lebih ke arah memenuhi dan melengkapi kebutuhan sehingga membantu agar tubuh pulih dari kondisi penyakit tertentu; suplemen kesehatan yang mengandung vitamin dapat melengkapi dan memperbaiki kekurangan vitamin tersebut dalam suatu kondisi tertentu, sehingga sistem imun dapat berfungsi optimal dalam kondisi tersebut; konsultasi pada dokter untuk memutuskan penggunaan suplemen kesehatan yang tepat.

c. Sistem imun

Ketika sistem imun atau daya tahan tubuh tidak berfungsi dengan baik maka tubuh dapat mengalami suatu penyakit hingga dapat menyebabkan kematian. Memiliki daya tahan tubuh yang baik adalah satu upaya dalam menghadapi COVID-19.

d. Informasi tentang vitamin $\mathrm{C}$

Vitamin $C$ atau dikenal sebagai asam L-askorbat, merupakan vitamin yang larut dalam air, secara alami ada dalam banyak makanan. Vitamin $\mathrm{C}$ dapat ditambahkan ke makanan lain atau sebagai suplemen kesehatan. Manusia tidak dapat mensintesis vitamin $\mathrm{C}$, sehingga harus diperoleh dari luar, yaitu dari makanan sebagai sumber utama.

e. Sumber-sumber vitamin C

Vitamin C secara alami terdapat dalam makanan yaitu jeruk, pisang, tomat, paprika, kol, blewah, kentang, bayam, kacang hijau.

f. Bagaimana vitamin $C$ bekerja untuk daya tahan tubuh

Vitamin $\mathrm{C}$ berkontribusi untuk daya tahan tubuh dengan mendukung berbagai fungsi seluler pada sistem kekebalan tubuh (innate immune dan adaptive immune).

g. Aturan di Indonesia terkait penggunaan vitamin C

Di Indonesia, batas maksimal penggunaan vitamin $\mathrm{C}$ sebagai suplemen kesehatan adalah $1000 \mathrm{mg} / \mathrm{hari}$

h. Pengertian COVID-19

COVID-19 adalah penyakit yang disebabkan oleh turunan coronavirus baru. "CO" diambil dari corona, "VI" virus, dan "D" disease (penyakit).

i. Upaya-upaya meningkatkan daya tubuh

Upaya untuk menghadapi COVID-19 yaitu dengan:

1. Upaya memutus rantai penyebaran virus dengan cara rutin mencuci tangan dengan sabun dan air mengalir atau gunakan handsanitizer berbasis alkohol; tutup hidung dan mulut saat bersin/batuk; social/physical distancing dan di rumah saja; gunakan masker.

2. Upaya meningkatkan daya tahan tubuh, yaitu dengan menerapkan gaya hidup sehat yaitu olahraga, istirahat cukup, cukup terapapar sinar matahari, makan makanan bergizi seimbang; serta konsumsi suplemen kesehatan bila perlu.

Peserta juga diedukasi terkait cara memilih produk suplemen kesehatan dengan benar yaitu dengan cek KLIK. Cek KLIK meliputi pengecekan Kemasan, Label, Izin edar, dan Kedaluwarsa. Semua peserta dilatih langsung untuk melakukan pengecekan pada suplemen kesehatan yaitu Vitamin C yang telah dibagikan. Peserta diedukasi untuk memastikan apakah kemasan produk dalam kondisi baik, tidak berlubang, sobek, karatan, penyok, dan bocor; 
membaca informasi produk yang tertera pada labelnya dengan cermat; memastikan produk memiliki Nomor Izin Edar dari Badan POM; serta memastikan produk tidak melebihi masa kedaluwarsa.

Peserta edukasi diberikan buku saku suplemen kesehatan yang diterbitkan oleh Badan Pengawas Obat dan Makanan Republik Indonesia pada tahun 2020. Pemberian buku saku kepada peserta bertujuan untuk memberikan informasi yang relevan dengan kondisi masyarakat Indonesia saat ini terkait suplemen kesehatan. Buku saku tersebut berisi materi dan informasi umum tentang suplemen kesehatan dan sistem daya tahan tubuh, informasi bahan suplemen kesehatan yang digunakan untuk memelihara kesehatan daya tahan tubuh serta informasi tambahan terkait pandemi COVID-19 di Indonesia.

Proses edukasi terhadap Kader Desa Sumbersuko berjalan baik dan lancar. Saat pemberian edukasi kepada Kader Desa terlihat bahwa masih banyak informasi yang masih belum diketahui terkait penggunaan suplemen kesehatan. Peserta yang merupakan Kader Desa sangat antusias dalam proses edukasi yang terbukti dengan munculnya banyak pertanyaan dari peserta saat sesi tanya jawab. Tanggapan Kader Desa yang baik terhadap kegiatan pengabdian masyarakat ini dapat terlihat dari respon yang positif saat proses pengabdian masyarakat berjalan. Para peserta edukasi nantinya akan menindaklanjuti informasi dan pengetahuan yang telah diberikan dengan cara berbagi informasi kepada masyrakat Desa. Kegiatan diakhiri dengan membagikan souvenir dan penutupan.

Pemberian edukasi kesehatan yang ditujukan untuk meningkatkan pengetahuan tentang Covid-19 bermanfaat untuk masyarakat agar memiliki sikap yang optimis dan tindakan yang sesuai dalam menghadapi Covid-19 (Zhong et al., 2020). Pemberian edukasi kepada Kader Desa merupakan upaya yang efektif karena nantinya Kader Desa yang umumnya dipercaya oleh masyarakat suatu Desa akan menyampaikan kembali informasi yang telah diperoleh. Dengan adanya kegiatan pengabdian masyarakat ini, tim pengabdian dapat membantu masyarakat dengan meningkatan pengetahuan Kader Desa terhadap penggunaan suplemen kesehatan yang merupakan salah satu upaya dalam menghadapi COVID-19.

\section{SIMPULAN}

Kegiatan pengabdian masyarakat tentang edukasi suplemen kesehatan dalam menghadapi Covid-19 yang dilaksanakan di Desa Sumbersuko Kabupaten Malang berjalan dengan baik dan lancar. Kader Desa memberikan respon yang positif dan dapat memahami informasi-informasi yang diberikan oleh tim pengabdian dengan baik. Tindak lanjut kedepannya yaitu para Kader Desa akan menyampaikan kembali hasil informasi dan pengetahuan yang telah didapatkan kepada masyarakat desa sehingga penggunaan suplemen kesehatan dapat digunakan secara tepat sebagai salah satu upaya untuk menghadapi Covid-19. Buku saku yang diberikan kepada Kader Desa dapat digunakan sewaktu-waktu ketika Kader Desa ingin mengulas kembali tentang materi terkait suplemen kesehatan.

\section{Ucapan Terima Kasih}

Kami mengucapkan banyak terima kasih kepada Institut Teknologi, Sains, dan Kesehatan RS dr. Soepraoen; Desa Sumbersuko Kecamatan Wagir Kabupaten Malang; serta semua pihak yang telah mendukung dan mensukseskan kegiatan pengabdian masyarakat ini.

\section{Daftar Pustaka}

Badan POM RI. (2019). Peraturan Badan Pengawas Obat dan Makanan Nomor 17 Tahun 2019 tentang Persyaratan Mutu Suplemen Kesehatan. 
Badan POM RI. (2020a). Buku Saku Suplemen Kesehatan untuk Memelihara Daya Tahan Tubuh dalam menghadapi COVID-19 Vitamin C. Badan POM.

Badan POM RI. (2020b). Pedoman Penggunaan Herbal dan Suplemen Kesehatan dalam Menghadapi COVID-19 di Indonesia.

Baj, J., Karakuła-Juchnowicz, H., Teresinski, G., Buszewicz, G., \& Ciesielka, M. (2020). COVID-19: Specific and Non-Specific Clinical Manifestations and Symptoms: The Current State of Knowledge. Journal of CLinical Medicine, 9(6), 1753.

Bozonet, S. M., \& Carr, A. C. (2019). The Role of Physiological Vitamin C Concentrations Healthy Individuals. 11(6), 1363. https://doi.org/10.3390/nu11061363

Carr, A. C.; Maggini, S. (2017). Vitamin C and immune function. Nutrients, 9(11), 1-25. https://doi.org/10.3390/nu9111211

Farjana, M., Moni, A., Sohag, A., Hasan, A., Hannan, A., Hossain, G., \& Uddin, J. (2020). Repositioning vitamin $\mathrm{C}$ as a promising option to alleviate complications associated with COVID-19. Infection \& Chemotherapy, 52(4), 461-477. https://doi.org/10.3947/ic.2020.52.4.461

Fehr, A. R., \& Perlman, S. (2015). Coronaviruses: An Overview of Their Replication and Pathogenesis. Coronaviruses, 1282(1), 1-23. https://doi.org/10.1007/978-1-4939-2438-7

Hemila, H. (2017). Vitamin C and infections. Nutrients, 9(4), 339. https://doi.org/10.3390/nu9040339

Hemilä, H., \& Chalker, E. (2013). Vitamin C for preventing and treating the common cold. Cochrane Database Systemic Reviews, 1. https://doi.org/10.1002/14651858.CD000980.pub4

Kashiouris M.G., L'Heureux M., Cable C.A., Fisher B.J., L. S. W. (2020). The emerging role of vitamin C as a treatment for sepsis. Nutrients, 12(292).

Kementerian Kesehatan Republik Indonesia. (2020). Pedoman Pencegahan dan Pengendalian Coronavirus Disease (Covid-19).

Menteri Kesehatan Republik Indonesia. (2020). Keputusan Menteri Kesehatan Republik Indonesia Nomor HK.01.07/MenKes/413/2020 Tentang Pedoman Pencegahan dan Pengendalian Corona Virus Disease 2019 (Covid-19).

Mishra, S., \& Patel, M. (2020). Role of Nutrition on Immune System During Covid-19 Pandemic. Journal of Food Nutrition and Health, 3(2).

PaLykkesfeldt, J. (2014). Vitamin C. Advances in Nutrition, 5(1), 16-18. https://doi.org/10.1126/science.177.4055.1152

Singhal, T. (2020). A Review of Coronavirus Disease-2019 (COVID-19). Indian Journal of Pediatric, 87(4), 281-286. https://doi.org/10.1007/s12098-020-03263-6

Wu, Y. C., Chen, C. S., \& Chan, Y. J. (2020). The outbreak of COVID-19: An overview. Journal of the Chinese Medical Association, 83(3), 217-220. https://doi.org/10.1097/JCMA.0000000000000270

Zhong, B. L., Luo, W., Li, H. M., Zhang, Q. Q., Liu, X. G., Li, W. T., \& Li, Y. (2020). Knowledge, attitudes, and practices towards COVID-19 among chinese residents during the rapid rise period of the COVID-19 outbreak: A quick online cross-sectional survey. International Journal of Biological Sciences, 16(10), 1745-1752. https://doi.org/10.7150/ijbs.45221 